\title{
Fighting or Conforming? Unitarian Opinion on Women and Culture
}

Brooke Palmer

Dr. James Duban (Faculty Editor)

Women's rights and roles differ greatly from culture to culture, making human rights a debated subject. The Unitarian religion in the nineteenth century upheld a liberal approach to these issues, as opinions among liberal Christians emerged from a nearly two-century transformation of orthodox Christianity to its liberal-Christian outlook. The process begins with Martin Luther's posting of his Ninety-Five Theses in 1517, effectively formalizing the Protestant movement in Western Europe. Protestantism spread rapidly, gaining strongholds in Germany and England. Henry VIII thereafter established and enforced Anglicanism - the Protestantism of the Church of England - as his kingdom's religion. Over time that evolved, via dissent, into Puritanism, some followers of which escaped persecution by colonizing the "New World" and practicing, in New England, a strict Protestantism, which advocated social obedience via the outlook that sanctification was evidence of justification. Attendant anxiety over one's justification became a de facto evidence of sanctification, implying that one was likely saved. That was so because the Puritans believed that only persons who experienced such anxiety already had the Holy Spirit within their souls, alerting them to the depth of their depravity, and thereby occasioning their anxiety. Enlightened American thinkers eventually found this to be oppressive, leading to the proliferation in the New World of such Protestant denominations as Arianism, Arminianism, and Antipedobaptism (i.e., Baptists), the last of which held that persons should not be baptized until they were fully capable of doctrinal commitment.

Such understanding implied an element of human rectitude, advancing an emergent confidence in human nature. Discounting an orthodox morphology of conversion that predicated salvation on the varied functions of a triad deity, the Unitarians instead exalted human nature by believing in one God who respected spiritual strivings and, eventually, humanity's obligation to imitate Christ's character. ${ }^{1}$ To publicize their convictions about the stellar potential of human nature, Unitarians published The Christian Inquirer, a nineteenth-century newspaper that contained opinionated articles about the home, society, spirituality, and the treatment of women across world cultures. Many articles insisted, as well, on the implementation of women's rights, though with uneven expectations for different societies. In this essay, I contend that, while Unitarians justly contended that women should be respected and better treated, liberal Christians, in their regard for trans-cultural phenomena, displayed biased outlooks at odds with the newspaper's advocacy of universal dignity and the essential equality of all persons before God. ${ }^{2}$

Moving beyond social expectations, Unitarians had a higher opinion of women, believing that they should be educated and treated with the respect. The Christian Inquirer featured many articles on women's roles in the home, work, society, and church. One article, "Beauty and Intelligence," notes that a woman's beauty should encompass consideration of her intellect. Similarly, the 
newspaper's comparison of the education of women to a treasure box emphasizes the Unitarian value of women in academics:

If the hours expended in contrivances for the adornment of the casket were employed for polishing the jewels within - if half the time, consumed in the consideration of a coiffure, or even in the arrangement of the corsage, were devoted to the moral training of the heart which beats within, and the developing the vast capabilities of that noble portion of the human frame which renders it the most beautiful and intelligent of created beings, woman would find her influence more powerful and unfailing; the admiration she would excite would be a sentiment compounded of esteemed respect, and love; and in rendering herself worthy of these, she would attain what the toilette, with all its attendant mysteries, is of itself insufficient. ${ }^{3}$

This outlook is indeed progressive. Women, a 'treasure box,' are likewise beautiful on the outside, while all know that what is most important is the moral sentiment, accompanied by intelligence and personality. The suggestion is that women should not be objectified; they should instead be an appreciated for both internal and external beauty. Unitarians further empower women by successfully refraining for shaming those who do care about their appearance. The author of "Beauty and Intelligence" does not disparage women who use their beauty to seduce men, as this act can be interpreted as a "laudable desire to influence him for his own comfort and happiness." The use of poetic language in the passage emphasizes how intelligence makes women beautiful because the prose of the paragraph itself is beautiful. While some may believe that this statement implies that women use their beauty only for the comfort of a man, the author sooner suggests that it is the choice of woman to make use of her physical appearance, which is indeed still empowering. Such Unitarian respect for the lady directly relates to how liberal Christians believed a woman should be treated by men.

The Christian Inquirer thus accentuates feminine value in "Woman and Flowers," where beauty is once again emphasized metaphorically, this time as gardening. ${ }^{4}$ Not only, claims the writer, do women resemble flowers "in beauty and sweetness," but they also deserve flowers and should grow alongside those. By implication, the man has that duty of building a garden for his wife and his daughters. A garden takes extensive care and delicacy to cultivate, placing more than just the job of gardener on the man of the household; indeed, his role is then expanded to care for the women and the "other flowers" in his house. The roles of men and women mentioned in this article suggest that Unitarians find more value in females than their being simple baby-makers. To the contrary, women are beautiful and important members of society.

The Christian Inquirer reiterates the importance of treating women well, singing praises regarding how societies in Turkey, Ethiopia, and America have treated women. The author of the article "Turkish Women" claims that a Turkish man treats his wife with respect, and not with an eye toward control or oppression. ${ }^{5}$ For example, Turkish husbands regard their wives as "the house" or "the home" and allow them to go out during the day as long their veils protect them from the state of "abuse." The author also argues that rather than being trapped as a caretaker, the wife is the ruler of her own home and "may receive her female friends 
and male relations." Although these examples of the expectations of women might suggest that Turkish society suppresses women, the writer emphasizes a few social role reversals suggesting otherwise. Examples of such respect include customs in the home and marriage: in place of an expected dowry from the wife during marriage, in Turkey it is the wife who receives a gift; and in the rule of law, women are given exclusive rights to the children. Beyond that, Turkish men are strongly encouraged to have only one wife, even though the law allows them up to four.

The positive outlook on modern gender customs also applies to American women in the newspaper. Since The Christian Inquirer was a Unitarian newspaper, the article presenting this subject, appropriately titled "American Women," first states a perception of the role of females in the United State and then counters this perception. ${ }^{6}$ The ladies are not treated as children, but as women;

traditional feminine activities are not to be praised, but to be discouraged because women use them to "in order not to think anything about work." Women are not to be denied work in literature and art, but to be encouraged to spend more time in the subjects because if women were to commit themselves, beyond housekeeping, to reading worthy topics, the world would advance in "literature and science."

The progressive Unitarian thoughts on women's roles span the Atlantic Ocean as well, emphasizing feminism on the European continent. In an article praising the beauties of women rather poetically, western European women assume roles similar to those of their American counterparts. ${ }^{7}$ The author compares women from the United States to those from England, France, Spain, and Italy in proximate words. For example, in reference to marriage, the author refers to man as marrying, uniting, cohabiting, and wedding, Although this would lead the reader to believe that there is little difference between an English woman and a French woman, the slight variation in verbs is attuned to differences in culture. And while this column lacks true descriptions of the roles of women in society and mentions only the perception of women, it nonetheless clarifies Unitarian favor for how men in these cultures behave.

A column that does address the place of women in society is summed up in the short but femininely empowering "Ethiopian Estimation of Women," in which the role of women in Ethiopian society is evaluated with both awe and admiration. ${ }^{8}$ In Ethiopia, there have been several reigning queens throughout royal history. In even more contrast to the rest of the world, genealogies are counted by females and tracked through the mothers. These three articles celebrate the fair treatment of women in four regions of the world: The Middle East, North America, West Europe, and East Africa. The implication is that Unitarians - granted, only up to a point — value feminine empowerment and respecting all cultures.

Still, not all cultural practices are praiseworthy: some elicit shock and curiosity, inconsistent with typical Unitarian thought on transcultural matters. One particular article, "Circassian and Armenian Women," evaluates an anecdote regarding young women from this society. ${ }^{9}$ Circassian women, on a small Turkish boat, were on their way to Constantinople to be sold as slaves when the Russians confiscated the ships. The women were given the choice either to return home, marry Russians or Cossacks of their choice; or to travel to Germany, where women are free; or go back to the Turkish captain to be sold.

Surprisingly, they unanimously choose to be 
sold. However, this is not unusual with regard to Eastern customs, since the buying and selling of women was common, down to their purchase for marriage. The article reveals that the buying of a woman brings her honor, since by offering money a man raises her value and liberates her from her family. Moreover, if she is sold for a large amount of money, the girl is said to have greater worth, including self-worth. Better chances, economically and socially, exist in Turkey, so Circassian women eagerly go there. Where there is more money, we read, they are treated with more kindness. By contrast, Armenian women are treated as equals until marriage, and then they are entirely concealed. The wife is gradually emancipated from such constraint after the birth of her first child. She is, however, not fully emancipated until after the lapse of six years. And even then, she can "never speak with any strangers of the other sex, nor appear before them unveiled."

The paper emphasizes that Circassians and Armenians are from the same region of the world, yet the treatment of women seems reversed. Nevertheless, both Armenian and Circassian women were suppressed in their respective societies. In other words, young Circassian women are sold as slaves, but are also allowed choices and liberation from their families, while Armenian women have liberty when they are young; but once married, they will never enjoy the same amount of freedom. The article explains these concepts in a way that informs without judgement; but placed in context of other columns written about women in The Christian Inquirer, such outlook does not coincide with the Unitarian standards championing the same liberties and freedoms for women as govern men. I suggest, therefore, that "Circassian and Armenian Women" implicitly suggests that, in accord with Unitarian outlook, the women from these groups should have greater rights. It is here, therefore, that inconsistency emerges in the "liberal" leanings of Unitarians, since cognitive dissonance emerges between the advocacy of feminist values and the cultural condensation implied in the questioning of distant foreign culture and norms.

In contrast to the attempts at an unbiased inquiry into women's rights in other countries, several columns protest the treatment of Chinese and Russian women. In "Women in China" the writer laments that Chinese society does not regard women as independent beings or even as companions to men. ${ }^{10}$ Rather, Chinese women are simply a slave to the needs, sexual and otherwise, of their husbands. Education for these girls is extremely limited - even for the nobles; the extent of female learning is limited to singing, embroidery, and playing on a "horrid three-stringed guitar." These activities are exclusively for leisure, rather than for the advancement of literature and science. Thus, even in education, what is taught to women is for recreation, not for necessity. Still, while the thrust of the article is proto-feminist, this review of a Chinese women's education goes unchallenged, without further research into whether some women have used their learning for the advancement of society. These issues disadvantage Chinese peasants even further: the farthest in society a young poor girl can go is to be purchased as a concubine. When compared to a similar article regarding Russian women, a pattern of prejudice emerges. "A Russian Wife Fair" describes young girls who present themselves for the chance of being selected for marriage. ${ }^{11}$ They arrange themselves in rows, dressed up as best as they can, and hoping for "love at first sight." The buying of selling of women, to the Unitarians, is completely immoral, whether or not this is clearly stated in a The Christian Inquirer column. The judgement passed by the author of these columns 
implies both a demand for more human rights, but also a subtle sense of xenophobia.

I have thus examined articles regarding the rights of women in a number of different regions, ranging from high editorial praise to outright disapproval, raising some intricate questions about crossculturalism and about cultural parity and condensation. In what ways are China and Turkey's societal treatment of women that different? What of Western Europe and Circassia? Unitarian opinion was mostly considered progressive regarding women's rights, but they were not so advanced that they considered intersectional feminism. Even when relying on information provided by the newspaper columns, numerous comparisons exist among social standards. This is problematic because of inconsistencies in moral standpoint. Both Turkish and Chinese culture place emphasis on patriarchal protectivism. The women were to be cared for and guided by their fathers; and after marriage, their husbands. Turkish and Chinese girls were also limited in their educational opportunities: they were mostly raised and educated to be housekeepers and mothers, not writers and scientists. Bias can be found in the articles because Turkish women's suffering and Chinese women's lack of political power is downplayed. Indeed, Turkish law placed strict rules on the rights for females to visit family and friends without attendance of their husbands; as limiting were places they could work outside the home. In contrast, the mother of the Emperor of China, the Empress Dowager, tended to have greatest political power in the country, despite her having to channel influence through the emperor rather than directly to the people. This is not to say that the information provided by The Christian Inquirer is false; rather, the facts the authors include were true, but rendered elliptical the entirety of the laws and cultural processes. Stated otherwise, the authors of these columns had good intentions but insufficient cultural understanding to cast informed judgement.

The comparison between West Europe and Circassia are similarly flawed. In the column describing Western European women, poetic comparisons are drawn among English, Spanish, Italian, and French women, all with similar connotations but various wording. The column regarding Circassian women, in contrast, is blunt and direct. It is therefore possible to understand the difference in perception by understanding the author's choice of prose. "Circassian and Armenian Women" directly states how women are regarded - as slaves to their husbands. Once again, there is more to the truth than the Unitarian writers provide. Whereas it may be true that Western European women are given more freedom compared to their Eastern European counterparts, they were still seen as inferior to men and as belonging to their fathers and husbands, even if it were not described as slavery. Unique to "Circassian and Armenian Women," however, the favorable rights of women are included, yet the discrepancies between the two columns cannot be overlooked.

We may speculate about why these inconstancies exist from column to column - ranging from different authors to blatant racism. Still, to the defense of The Christian Inquirer, the reasons the articles pass stricter judgment on some societies than on others may simply be that some authors believed in a fairer treatment of women; and that these stern believers wrote the articles on Armenia and China, while more lenient writers explored Western Europe and Turkey. Unfortunately, it is not possible to confirm or deny this theory, as nineteenth-century newspapers tended not to identify the authors; only editors. It is exclusively the range of time over which 
these articles appeared (1846-1863) which would imply that there were authors with differing opinions. When considering this time period, one must also recognize race relations in the United States. White supremacy was still rampant and certainly less discouraged than it would soon become, so it is possible that Unitarian writers were inclined to view cultures similar to their own more favorably. This would explain why Western European culture is viewed positively whereas Chinese culture faces harsh criticism. This also accounts for the failure of Unitarian writers to condemn American social standards. The flaw in such outlook lies with Turkish and Eastern European society, in which Armenia and Circassia are arguably more similar to America than to Turkey, although this may have been the case because treatment of women in Armenia and Circassia was harsher than in Turkey. Some authors and researchers tend to be more critical when writing in anthropological subjects, but few are able to transcend the prejudicial thought of their time and culture, or to resist filling in the gaps of knowledge with their own preconceptions.

Societal expectations of the nineteenth century in the United States placed significantly more emphasis on the straight white man than is the case today; thus, despite being liberal thinkers, Unitarian writers were subject to conventional thought. Unitarian outlook did not - with the exception of such advanced thinkers such as Margaret Fuller - include women's role in politics, leadership, or as individuals without a husband. Nor was there a consistent emphasis on the rights of people of color. Long-term advancement of oppressed groups would continue to take a century, through protests, enlightened thinkers, and judicial court cases. The Christian Inquirer is not to be faulted, however, for arguably initiating and inspiring such progress, via consideration of an elevated view of human nature and a desire to explore and credit cross-cultural values. A long-term transformation from Calvinist Puritanism, to Arminianism, to Unitarianism, and finally to

Transcendentalism allowed for the gradual liberalization of Christianity, leading up to The Christian Inquirer's global inquiry into the condition of women. Unitarian thought thus advanced modern-day views far more significantly than one may initially realize.

\section{Notes}

1. For more information on the development of Unitarianism, see Duban, James. "Conscience and Consciousness: The Liberal Christian Context of Thoreau's Political Ethics." The New England Quarterly 60, no. 2 (1987): 208-22. Accessed September 4, 2020. doi: $10.2307 / 365606$.

2. For more reading on the development of feminist thought during this period, see: Fuller, Margaret. Woman in the Nineteenth Century: With an Introduction. by Bernard Rosenthal. Norton, 1980.

3. "Beauty and Intelligence." The New York Christian Inquirer, 3 Sept. 1856, p. 1, col. 2 .

4. "Women and Flowers." The New York Christian Inquirer, 28 July 1849, p. 4, col.

5. "Turkish Women." The New York Christian Inquirer, 22 April 1854, p. 4, col. 1

6. "American Women." The New York Christian Inquirer, 1836, p. 1, col 2-3.

7. "The Women of Different Nations." The New York Christian Inquirer, 7 July 1855 , p. 4 , col. 3. 
8. "Ethiopian Estimation of Women." The New York Christian Inquirer, 28 May 1863, p. 4, col 2.

9. "Circassian and Armenian Women." The New York Christian Inquirer, 24 March 1855, p 4, col 2-3.
10. "Women in China." The New York Christian Inquirer, 26 Feb. 1853, p. 4, col. 1.

11. "A Russian Wife Fair." The New York Christian Inquirer, 28 June 1849, p. 4, col. 3 